\title{
Selected Aspects of Cooperation between Kindergarten Teachers and Institutions / Organizations - A Statement from the Research Conducted in Poland
}

\author{
Ewa Wyczółkowska \\ Faculty of Social Sciences, Institute of Pedagogy, Siedlce University of Natural Sciences and Humanities, Poland
}

Received March 24, 2021; Revised June 7, 2021; Accepted June 20, 2021

\section{Cite This Paper in the following Citation Styles}

(a): [1] Ewa Wyczótkowska, "Selected Aspects of Cooperation between Kindergarten Teachers and Institutions / Organizations - A Statement from the Research Conducted in Poland," Universal Journal of Educational Research, Vol. 9, No. 8, pp. 1487 - 1500, 2021. DOI: 10.13189/ujer.2021.090801.

(b): Ewa Wyczótkowska (2021). Selected Aspects of Cooperation between Kindergarten Teachers and Institutions / Organizations - A Statement from the Research Conducted in Poland. Universal Journal of Educational Research, 9(8), 1487 - 1500. DOI: 10.13189/ujer.2021.090801.

Copyright $\bigcirc 2021$ by authors, all rights reserved. Authors agree that this article remains permanently open access under the terms of the Creative Commons Attribution License 4.0 International License

\begin{abstract}
The article presents the research on the cooperation of kindergarten teachers with institutions / organizations. The creation of the vision of a new model of this cooperation required examining the prevailing relations at this level and learning the determinants influencing the activities undertaken by the partners. For this purpose, a research was conducted in Poland in 20162017. It was preceded by the pilot study carried out in 2015. The participants of the research in the pilot study were parents of preschool children and kindergarten teachers from villages and towns in the Mazowieckie Voivodeship, and representatives of institutions / organizations cooperating with the kindergartens in the Mazowieckie Voivodeship. In the relevant research, three microsystems were taken into account: parents; teachers working in kindergartens in rural areas, cities and all over Poland; and representatives of institutions / organizations cooperating with kindergarten teachers globally. The data analysis made it possible to select the strengths and weaknesses of cooperation between Polish kindergarten teachers and institutions / organizations. As a result, a based on 9 theses model of cooperation between kindergarten teachers and institutions was created, and the following paradigms were identified: cooperation requires partners' self-reflection, cooperation is based on working at oneself, cooperation creates empathy and trust, cooperation expands linguistic and cultural capital, cooperation that offers a new quality of life in partnership relations is a product of transformations
\end{abstract}

taking place over time.

Keywords Cooperation, Kindergarten, Institutions / Organizations, General Goals, Forms of Action, Determinants Influencing Cooperation, Attitudes, Benefits, Communication

\section{Introduction}

Life in the twenty-first century moves very fast; loved ones have no time for one another. The handicap known as "constant work" is deeply rooted in the interpersonal relationships.

An important task is assigned to schools / kindergartens, which must guide the participants of the educational process in such a way that the need for a deeper understanding of freedom arises in them that means being themselves and free from what is enslaving them. $[2,3,6]$ There is no doubt that, the postulated concept of educating children and adolescents included in the slogan: "coherence of educational activities among school, family, and other institutions" [34] already at the stage of preparation of the reform in Poland (1999), answered the discussed crisis situations. [47] Likewise, at the international stage, the so-called Delores Report played its role in preparing a new space for cooperation. [48] The 
reflection on democratic schools / kindergartens based on the idea of cooperation is a driving force to ease tensions and create conditions to overcome troublesome situations. Obtaining the cooperation of the dialogue partners requires the initiation of upbringing tasks, i.e. changes in the child's psyche and behaviour. The upbringing measures should be aimed at improving and developing a chain of changes that includes emotional and volitional experiences, their dispositions and progress. Thus, "The task of upbringing is to make the chain of changes possibly consistent with the values indicated by the general goals of upbringing as durable as possible and, moreover, perceived and controlled by the individual being brought up".[30, 31] Hence, as a result of the variety of the undertaken upbringing activities corresponding to the needs of the individual, experiences, aspirations and interests are stimulated, which is the basis for establishing relationships. Wincenty Okoń described the collaboration of units that perform their tasks in an atmosphere of trust and loyalty in order to achieve the set goal as cooperation.[25] The cooperation of kindergarten teachers with institutions / organizations covers a number of forms of collaboration in four areas, which include: integrating the participants of the upbringing, educational and teaching-learning process; supporting the educational role of entities involved in bringing up a child; information flow about the child; helping the institution in creating favourable working conditions. It is obvious that the contemporary Polish kindergarten is no longer the only place where children develop physically, mentally, emotionally and socially, as well as it is not the only place providing support in the area of early diagnosis and therapy either. Polish children also build their knowledge and skills during classes in the external entities from an early age. The transformation that has taken place in the Polish society since the decentralization of the education system has resulted in kindergartens being included in a number of local, national and international activities. This prompted Polish pedagogues and sociologists of upbringing, as well as other people interested in the problem, to explore the discussed topic.[7, 43, 44, 45, 46] Reports on the cooperation of kindergartens with institutions / organizations can be found in popular science and scientific articles written in journals, or as chapters in multi-author monographs. Reports on international and national projects [52] as well as reports on internal and external evaluation of Polish kindergartens are also a rich source of data.[51] Opening kindergartens to external entities in a global context allows for the preparation of a child for life in the society.

The aforementioned assumptions became the starting point for the design of the research presented in this article. The subject of the research is the cooperation of kindergarten teachers with institutions / organizations. The research is aimed at diagnosing the process of cooperation between Polish kindergarten teachers and institutions / organizations; as a consequence, at identifying the strengths and weaknesses of the actions taken, and at constructing a model of cooperation based on the progressive development of four-entity relationships. The synergy includes the child - parent $-\mathrm{a}$ kindergarten teacher - a representative of the institution / organization in the space of joint action. The search for a new model of cooperation combining the ability of existence, being with oneself and at the same time with others, as well as following a creative path, offers a new quality of life in relations among partners. Therefore, we should focus on finding solutions at the level of a child parents - a kindergarten teacher - a representative of the institution / organization in the process of maturation towards creative self-realization of each of the cooperation partners. Consequently, the reference was made to the basic elements of cooperation programs developed in Polish kindergartens, namely the goals of cooperation, forms of action and other determinants (i.e. attitudes, communication, and other determinants influencing cooperation). For the relevance of the research, the study focused on the frequency of indications of the above-mentioned components of cooperation programs, the consistency of the respondents' statements, as well as noticing the relationship between the appropriate answers.

\section{Methodology}

Creating a vision of a new model of cooperation between kindergarten teachers and institutions / organizations requires examining the prevailing relations at this level and investigating the determinants influencing the activities undertaken by partners. For this purpose, the following questions of research were formulated:

Question 1: What determinants most often affect the cooperation of kindergarten teachers with institutions / organizations?

Question 2: In the case of which determinants are the respondents' statements consistent?

Question 3: What determinants correlate with each other?

In search of answers to the questions posed, the research was conducted in Poland in 2016-2017. It was preceded by pilot study ${ }^{1}$ [17], run in $2015 .^{2}$

1 Apart from the researcher, the research was conducted by students of the 3rd year of Early Childhood Education with Pre-school Education from the University of Natural Sciences and Humanities in Siedlce in the $2014 / 2015$ academic year. The results of the analysis of the results collected in the pilot studies were published in the article: Jagiełło E., "Cooperation as element of well-balanced child's development," $9^{\text {th }}$ International Conference on Education and New Learning Technologies Barcelona, Spain 3-5 July, 2017, Publisher: IATED. DOI: https://doi.org/10.21125/edulearn.2017, pp. 8868-8879.(*)

2 In the further statistical analysis of the expressions: Parents who comment on the cooperation of kindergarten teachers with institutions / organizations; Teachers who cooperate with institutions; Institutions / organizations that cooperate with kindergarten teachers will be replaced with the following notions: 'Parents about institutions', 'Teachers about 
The presented research project was embedded in the quantitative (nomothetic) research strategy. This strategy allowed the collection of data to describe a large population based on a well-matched group of respondents that was part of it. It was assumed that the characteristics of the selected people approximate the characteristics of the entire population, and the constructed questionnaires will provide data the same way as for all members of the given population. Ultimately, 531 representatives of institutions / organizations cooperating with kindergartens participated in the research ${ }^{3}$. Most of the respondents represented other educational institutions (14.00\%). Most of the institutions / organizations whose representatives participated in the survey cooperated with kindergartens for more than 25 years $(32.60 \%)$, and the least $(6.60 \%)$ from 21 to 25 years. Thus, most of the institutions / organizations had impressive theoretical knowledge and extensive practical experience.

The following methods turned out to be the most advantageous for seeking answers to the research problems: document analysis, estimation method (grading scale), survey method [22], and snowball method [1]. The answers of the respondents were counted and analysed using properly selected mathematical and statistical tools. The analysis of the study results was performed in IBM SPSS Statistics 25.00 program. Due to the large number of respondents, I used the chi-square test proposed by Karl Pearson [8] [33]. The nonparametric U Mann-Whitney test was used due to testing the differences between two independent samples [33] [9]. Additionally, the Kruskal-Wallis Statistics belonging to the group of nonparametric tests were used, which is a generalization of the Mann-Whitney $U$ test in the case of comparing more than two groups of independent numbers. The use of the Kruskal-Wallis test became justified, because the variables were quantitative, but did not meet the required assumptions of the parametric tests [19] [20]. To show the strength of the demonstrated relationship between the determinants, a Multiple Correspondence Analysis MCA was used. The Multiple Correspondence Analysis MCA is an exploratory technique for categorizing variables.[5] [49] For quantitative variables, MCA variants such as the PCA [39], CCPCA [40] [41] and GPCA [42] are used.

institutions' and 'Institutions about teachers'. Whereas, in general, I will replace all the groups of respondents from the database "institutions / organizations" with the notion "Respondents about institutions".

3 In the further statistical analysis of the expressions: Parents who comment on the cooperation of kindergarten teachers with institutions organizations; Teachers who cooperate with institutions; Institutions / organizations that cooperate with kindergarten teachers will be replaced with the following notions: 'Parents about institutions', 'Teachers about institutions' and 'Institutions about teachers'. Whereas, in general, I will replace all the groups of respondents from the database "institutions / organizations" with the notion "Respondents about institutions".

\section{Analysis of the Research Results}

By adopting the paradigm of multiagency and public perspective of the process of cooperation between kindergarten teachers and institutions / organizations, I will indicate the determinants of cooperation are most likely determined by the entities involved in the planning and implementation of care-educational and schooling interaction services.

In the light of the research analysis, it was found that in the case of the goals of cooperation between kindergarten teachers and institutions / organizations, only certain areas that are important for 'Respondents and institutions' can be mentioned. Thus, for 'Respondents about the institution' the social goals $(50.50 \%)$ and development goals $(47.20 \%)$ were at a fairly comparable level. The 'Respondents about the institution' had a low appreciation of the cultural goals $(32.36 \%)$ in the cooperation of kindergarten teachers with institutions / organizations. The data contained in Table 1 provided the information that among the collective forms of activity 'Institutions about teachers' significantly indicated meetings on upbringing difficulties (40.96\%). Other determinants were marked much less frequently, quite rarely 'Institutions about teachers' chose meetings with an expert (20.99\%). On the other hand, for the 'Institution about teachers' a moderately often used individual form of activity in cooperation with kindergarten teachers was phone calls $(42.17 \%)$. A low level of indications was observed in the case of other variables within this group, and the lowest was for additional individual forms (22.38\%). When analysing the other determinants influencing the cooperation of kindergarten teachers with institutions / organizations, the most important thing for the respondents was the atmosphere of cooperation (75.21\%), they significantly emphasized the duration of cooperation (50.38\%), and they assigned a low role to the characteristics of cooperation partners (35.26\%). Moreover, communication as a determinant of cooperation on communication at a high level was assessed as low $(2.96 \%)$ by 'Respondents about the institution'. The research provided the information that 'Respondents about the institution' very strongly define their attitudes as positive attitudes $(93.75 \%)$.

The analysis of the general averages in the table implied that all groups, i.e., children, parents and grandparents, teachers, institutions / organizations, benefited almost with the same significant frequency. It is difficult to say which benefits best define the cooperation of kindergarten teachers with institutions / organizations. 
Table 1. Descriptive statistics for 'Respondents about the institution' ${ }^{4}$ with a differential test by group

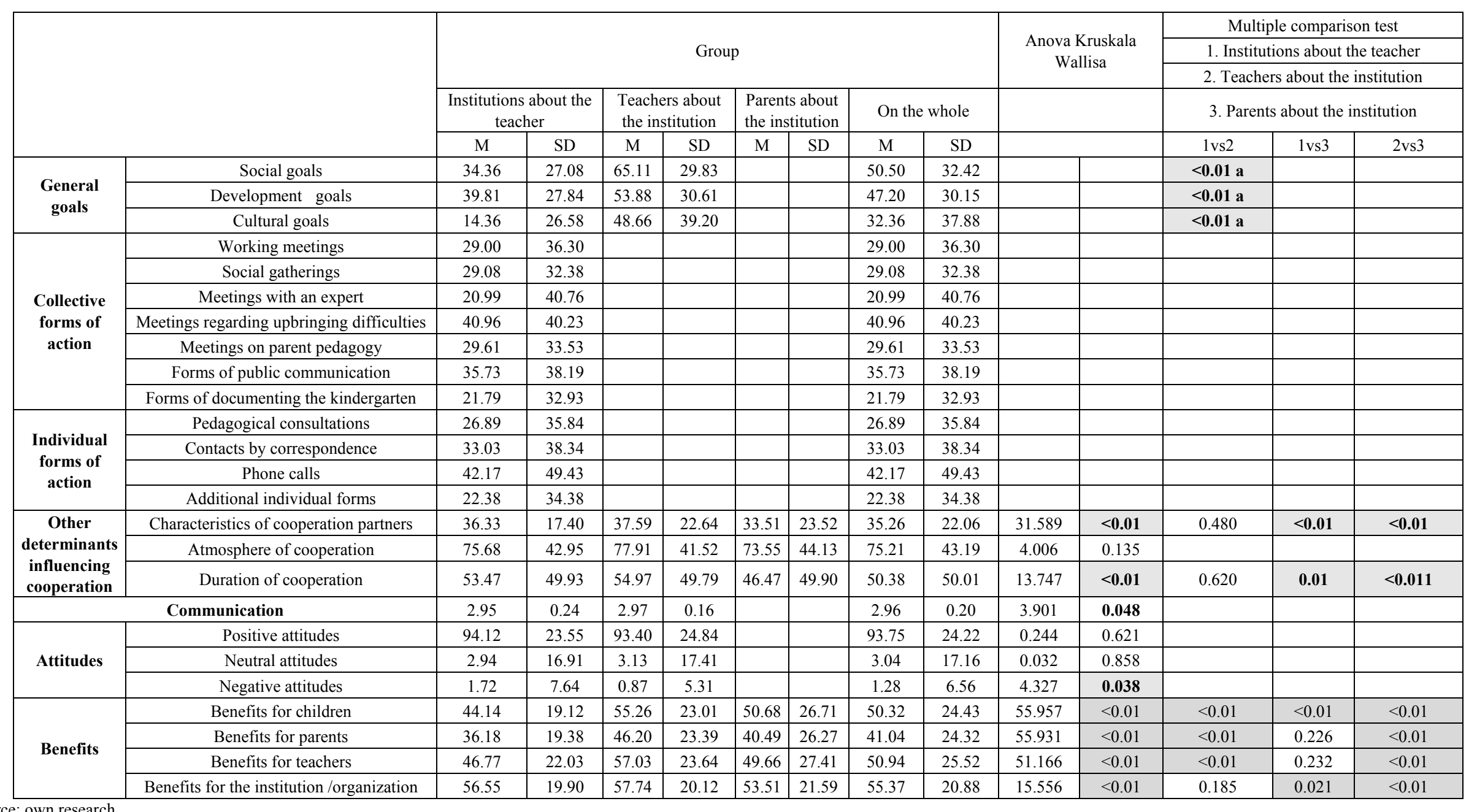

Source: own research

Note: M-medium; SD-standard deviation; Chi2-statistics of the Anov Kruskal Wallis test; a - for the comparison of the two groups, Anov Kruskal Wallis was not counted, but only U Mann Whitney's;

Significant differences in the means are marked in grey;

I do not include the low and average level of communication in the model, as they are small and, therefore, do not relate to other determinants

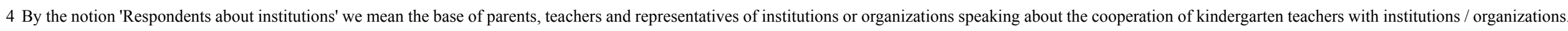


Table 2. Coefficients of the multidimensional analysis of MCA correspondence for 'Respondents about institutions' (Chi2 $(1681)=29474.0 ; \mathrm{p}<0.01)$

\begin{tabular}{|c|c|c|c|c|c|c|c|c|c|c|}
\hline & $\begin{array}{c}\text { Row } \\
\text { Number }\end{array}$ & $\begin{array}{c}\text { Coordinates. } \\
\text { Dimension1 } \\
\end{array}$ & $\begin{array}{l}\text { Coordinates. } \\
\text { Dimension2 } \\
\end{array}$ & Mass & Quality & $\begin{array}{l}\text { Relative } \\
\text { inertia. }\end{array}$ & $\begin{array}{c}\text { Inertia. } \\
\text { Dimension1 }\end{array}$ & $\begin{array}{c}\operatorname{Cos}^{\wedge} 2 \\
\text { Dimension1 }\end{array}$ & $\begin{array}{c}\text { Inertia. } \\
\text { Dimension2 }\end{array}$ & $\begin{array}{c}\operatorname{Cos}^{\wedge} 2 \\
\text { Dimension2 }\end{array}$ \\
\hline Working meetings:- & 1 & -0.457 & 0.032 & 0.038 & 0.779 & 0.010 & 0.026 & 0.776 & 0.000 & 0.004 \\
\hline Working meetings:+ & 2 & 1.698 & -0.119 & 0.010 & 0.779 & 0.038 & 0.097 & 0.776 & 0.001 & 0.004 \\
\hline Social gatherings:- & 3 & -0.422 & 0.035 & 0.036 & 0.536 & 0.012 & 0.021 & 0.532 & 0.000 & 0.004 \\
\hline Social gatherings:+ & 4 & 1.260 & -0.105 & 0.012 & 0.536 & 0.036 & 0.063 & 0.532 & 0.001 & 0.004 \\
\hline Meetings with an expert:+ & 5 & 1.322 & 0.140 & 0.010 & 0.487 & 0.037 & 0.060 & 0.482 & 0.002 & 0.005 \\
\hline Meetings with an expert:- & 6 & -0.364 & -0.038 & 0.037 & 0.487 & 0.010 & 0.016 & 0.482 & 0.000 & 0.005 \\
\hline $\begin{array}{l}\text { Meetings regarding } \\
\text { upbringing difficulties:- }\end{array}$ & 7 & -0.467 & 0.010 & 0.036 & 0.658 & 0.012 & 0.026 & 0.657 & 0.000 & 0.000 \\
\hline $\begin{array}{c}\text { Meetings regarding } \\
\text { upbringing difficulties: }+\end{array}$ & 8 & 1.408 & -0.030 & 0.012 & 0.658 & 0.036 & 0.078 & 0.657 & 0.000 & 0.000 \\
\hline $\begin{array}{c}\text { Meetings on parent } \\
\text { pedagogy:- }\end{array}$ & 9 & -0.445 & 0.019 & 0.038 & 0.771 & 0.010 & 0.025 & 0.770 & 0.000 & 0.001 \\
\hline $\begin{array}{l}\text { Meetings on parent } \\
\text { pedagogy: }+\end{array}$ & 10 & 1.732 & -0.072 & 0.010 & 0.771 & 0.038 & 0.097 & 0.770 & 0.000 & 0.001 \\
\hline $\begin{array}{l}\text { Forms of public } \\
\text { communication:- }\end{array}$ & 11 & -0.497 & 0.091 & 0.031 & 0.462 & 0.017 & 0.025 & 0.447 & 0.002 & 0.015 \\
\hline $\begin{array}{l}\text { Forms of public } \\
\text { communication: }+\end{array}$ & 12 & 0.899 & -0.165 & 0.017 & 0.462 & 0.031 & 0.046 & 0.447 & 0.004 & 0.015 \\
\hline $\begin{array}{l}\text { Forms of documenting the } \\
\text { kindergarten:- }\end{array}$ & 13 & -0.388 & -0.019 & 0.039 & 0.656 & 0.009 & 0.019 & 0.654 & 0.000 & 0.002 \\
\hline $\begin{array}{c}\text { Forms of documenting the } \\
\text { kindergarten:+ }\end{array}$ & 14 & 1.687 & 0.083 & 0.009 & 0.656 & 0.039 & 0.084 & 0.654 & 0.001 & 0.002 \\
\hline $\begin{array}{c}\text { Pedagogical } \\
\text { consultations:- }\end{array}$ & 15 & -0.466 & -0.014 & 0.036 & 0.684 & 0.011 & 0.026 & 0.683 & 0.000 & 0.001 \\
\hline $\begin{array}{c}\text { Pedagogical } \\
\text { consultations: }+\end{array}$ & 16 & 1.466 & 0.044 & 0.011 & 0.684 & 0.036 & 0.082 & 0.683 & 0.000 & 0.001 \\
\hline $\begin{array}{l}\text { Contacts by } \\
\text { correspondence:- }\end{array}$ & 17 & -0.488 & -0.012 & 0.031 & 0.461 & 0.016 & 0.025 & 0.461 & 0.000 & 0.000 \\
\hline $\begin{array}{c}\text { Contacts by } \\
\text { correspondence: }+\end{array}$ & 18 & 0.945 & 0.023 & 0.016 & 0.461 & 0.031 & 0.048 & 0.461 & 0.000 & 0.000 \\
\hline Phone calls:- & 19 & -0.405 & -0.074 & 0.027 & 0.230 & 0.020 & 0.015 & 0.222 & 0.001 & 0.007 \\
\hline Phone calls:+ & 20 & 0.549 & 0.101 & 0.020 & 0.230 & 0.027 & 0.020 & 0.222 & 0.002 & 0.007 \\
\hline $\begin{array}{l}\text { Additional individual } \\
\text { forms:- }\end{array}$ & 21 & -0.258 & 0.017 & 0.042 & 0.535 & 0.005 & 0.009 & 0.532 & 0.000 & 0.002 \\
\hline $\begin{array}{c}\text { Additional individual } \\
\text { forms: }+\end{array}$ & 22 & 2.066 & -0.139 & 0.005 & 0.535 & 0.042 & 0.075 & 0.532 & 0.001 & 0.002 \\
\hline
\end{tabular}


Table 2 Continued

\begin{tabular}{|c|c|c|c|c|c|c|c|c|c|c|}
\hline $\begin{array}{c}\text { Characteristics of } \\
\text { cooperation partners:- }\end{array}$ & 23 & -0.065 & 0.048 & 0.040 & 0.036 & 0.007 & 0.001 & 0.023 & 0.001 & 0.012 \\
\hline $\begin{array}{c}\text { Characteristics of } \\
\text { cooperation partners:+ }\end{array}$ & 24 & 0.355 & -0.260 & 0.007 & 0.036 & 0.040 & 0.003 & 0.023 & 0.004 & 0.012 \\
\hline $\begin{array}{l}\text { Atmosphere of } \\
\text { cooperation: }+\end{array}$ & 25 & 0.059 & -0.029 & 0.036 & 0.014 & 0.011 & 0.000 & 0.011 & 0.000 & 0.003 \\
\hline $\begin{array}{l}\text { Atmosphere of } \\
\text { cooperation:- }\end{array}$ & 26 & -0.189 & 0.093 & 0.011 & 0.014 & 0.036 & 0.001 & 0.011 & 0.001 & 0.003 \\
\hline Duration of cooperation: + & 27 & 0.079 & 0.114 & 0.025 & 0.022 & 0.022 & 0.001 & 0.007 & 0.003 & 0.015 \\
\hline Duration of cooperation:- & 28 & -0.091 & -0.131 & 0.022 & 0.022 & 0.025 & 0.001 & 0.007 & 0.003 & 0.015 \\
\hline Communication: + & 29 & 0.010 & 0.214 & 0.045 & 0.858 & 0.002 & 0.000 & 0.002 & 0.017 & 0.856 \\
\hline Communication:- & 30 & -0.195 & -4.008 & 0.002 & 0.858 & 0.045 & 0.000 & 0.002 & 0.327 & 0.856 \\
\hline Positive attitudes: ${ }^{+}$ & 31 & 0.015 & 0.223 & 0.045 & 0.870 & 0.003 & 0.000 & 0.004 & 0.019 & 0.866 \\
\hline Positive attitudes:- & 32 & -0.260 & -3.877 & 0.003 & 0.870 & 0.045 & 0.001 & 0.004 & 0.330 & 0.866 \\
\hline Neutral attitudes:- & 33 & 0.008 & 0.146 & 0.046 & 0.667 & 0.001 & 0.000 & 0.002 & 0.008 & 0.666 \\
\hline Neutral attitudes: ${ }^{+}$ & 34 & -0.236 & -4.552 & 0.001 & 0.667 & 0.046 & 0.000 & 0.002 & 0.260 & 0.666 \\
\hline Negative attitudes:- & 35 & 0.002 & -0.001 & 0.048 & 0.002 & 0.000 & 0.000 & 0.001 & 0.000 & 0.001 \\
\hline Negative attitudes: + & 36 & -0.822 & 0.583 & 0.000 & 0.002 & 0.048 & 0.000 & 0.001 & 0.000 & 0.001 \\
\hline Social goals:- & 37 & -0.154 & 0.025 & 0.029 & 0.038 & 0.019 & 0.002 & 0.037 & 0.000 & 0.001 \\
\hline Social goals:+ & 38 & 0.237 & -0.039 & 0.019 & 0.038 & 0.029 & 0.004 & 0.037 & 0.000 & 0.001 \\
\hline Development goals:- & 39 & -0.019 & 0.059 & 0.024 & 0.004 & 0.024 & 0.000 & 0.000 & 0.001 & 0.003 \\
\hline Development goals: + & 40 & 0.018 & -0.058 & 0.024 & 0.004 & 0.024 & 0.000 & 0.000 & 0.001 & 0.003 \\
\hline Cultural goals:- & 41 & -0.027 & 0.083 & 0.035 & 0.022 & 0.012 & 0.000 & 0.002 & 0.002 & 0.020 \\
\hline Cultural goals: + & 42 & 0.080 & -0.242 & 0.012 & 0.022 & 0.035 & 0.000 & 0,002 & 0.006 & 0.020 \\
\hline
\end{tabular}

Source: own research

Note: I do not include the low and average level of communication in the model, as they are small and, therefore, do not relate to other determinants. 
In the next part of the publication, the consistency of answers to individual questions will be examined among three subgroups of respondents: 'Teachers about the institution', 'Institutions about teachers' and 'Parents about the institution'. This will allow the in-depth verification of the respondents' answers. Searching for correlation between the variables (determinants), the Multidimensional Correspondence Analysis (MCA) method was used, which allows the verification of the coexistence of several nominal features describing the objects. The results obtained with this tool will be presented in the form of a map of points in a two-dimensional space, the so-called matrix.

Table 2 presents the data specifying answers to the most important questions for the studied groups of people. The quality of the results $>0.5$ indicates strong discriminant properties for the model. This means that the obtained results are highly reliable, in particular the values $>$ 0.7 are very strong.

The MCA analysis for 'Respondents about the institution' provides a lot of important multidimensional relationships. For example, it is noticeable that the 'Respondents about the institution' simultaneously declare working meetings, meetings on parent pedagogy, communication and positive attitudes, as the most frequently suggested partner activities for collaboration between kindergarten teachers and institutions / organizations. With less force, but also with high probability, the respondents indicate pedagogical consultation, meetings on upbringing difficulties, neutral attitudes, forms of documenting kindergarten, social meetings, and additional individual forms, not individually, but in connection with each other. The respondents pointed out to meetings with an expert, forms of public communication, and contacts by correspondence with moderate probability. It is worth noting that 'Respondents about institutions' representing particular groups of cooperation strongly emphasize the importance of positive attitudes among partners, and their level of communication is assessed a high level of communication. Going deeper into the detailed data, it was noticed that in the group of 'Respondents about institutions', both 'Institutions about teachers' and 'Teachers about institutions' form a significant subgroup, whereas the studied subgroup 'Parents about institutions' did not show significant relationships.

In fact, the acquired data initiate reflections on the correlations between highly accentuated variables (which proves the consistency of the statement) and other variables. The main effect of the analysis of the data presented in the table is the scatter plot, called a perceptual map (matrix).

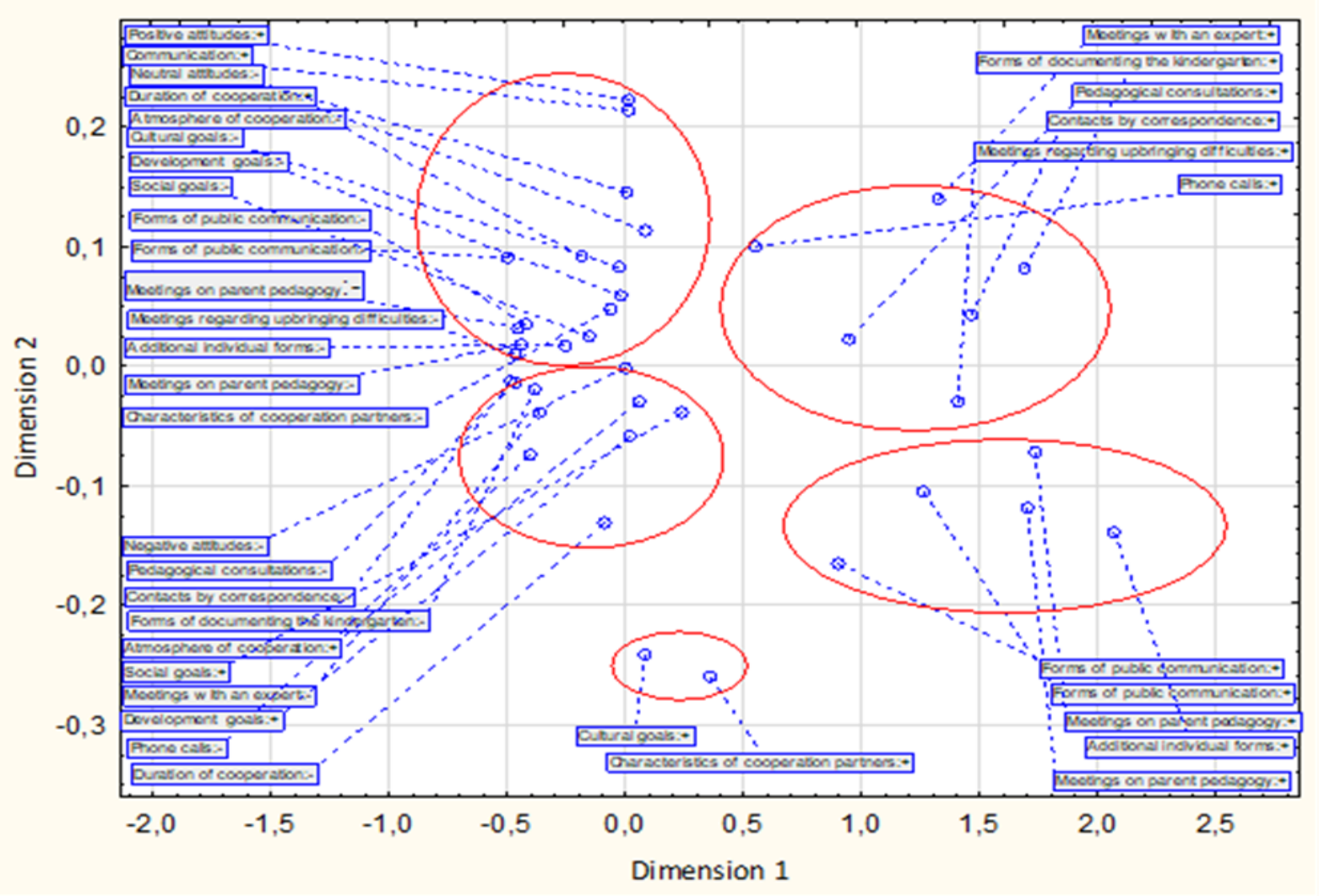

Picture 1. The matrix of the multidimensional analysis of MCA correspondence for 'Respondents about the institution' 
The above chart allows to answer the questions as to which determinants are the most likely and what are the connections among them intuitively. Ultimately, five states of aggregation were obtained. As can be seen in the matrix, the first state of aggregation is represented by the most likely positive attitudes. In this ellipse, I read that positive attitudes, communication, and duration of cooperation are statistically significant. Moreover, the shortest distance is between the positive attitudes and the communication that speaks of their strong correlation. The distance between the positive attitudes and the duration of cooperation is longer, in other words, there is a moderate correlation between them. The correlation between the high level of communication and the duration of cooperation remains at a weak level. On the other hand, if 'Respondents about the institution' emphasize positive attitudes, they do not consider neutral attitudes, atmosphere of cooperation, cultural goals, development goals, social goals, social gatherings, forms of collective communication, working meetings, meetings regarding upbringing difficulties, additional individual forms, meetings on parent pedagogy, characteristics of cooperation partners of great importance.

There is no doubt that in the second state of aggregation 'Respondents about the institution', while strongly pointing to the atmosphere of cooperation, are also likely to choose social goals and development goals. Based on the distance between the points representing the variables mentioned, I conclude that there is a strong correlation between the social goals and the development goals. A weak correlation is between the development goals and the atmosphere of cooperation, and between the social goals and the atmosphere of cooperation. On the other hand, 'Respondents about the institution' put the main emphasis on the atmosphere of cooperation in the absence of indications of negative attitudes, pedagogical consultations, contacts by correspondence, forms of documenting the kindergarten, meetings with an expert, phone calls, and duration of cooperation.

On the basis of the illustrated relationships in the third state of aggregation, it can be seen that cultural goals strongly correspond with the characteristics of cooperation partners.

The fourth state of aggregation includes the following variables: forms of collective communication, social gatherings, and meetings on parent pedagogy, additional individual forms and working meetings. They are consistent with each other, and the strength of the correlation is determined by the distance between the points on the graph. Observing the location of the points, it can be concluded that meetings on parent pedagogy strongly correlate with the working meetings. The coexistence between the meetings on parent pedagogy and the additional individual forms remains at a moderate level, with attention to social meetings, and the correlation is significant moderately for the variables additional individual forms and working meetings. Moreover, at a moderate level, there is a relationship between the forms of collective communication and the social gatherings. The weakest level of consistency is between the additional individual forms and the social gatherings, paying attention to the forms of collective communication, and between the meetings on parent pedagogy and the forms of collective communication. The location of the points representing the forms of collective communication and the working meetings also shows that the relationship between these variables is weak. The situation is comparable in the case of social gatherings and working meetings; 'Respondents about the institution' make poor choices of both variables.

The fifth state of aggregation displayed on the matrix covers statistically significant determinants. 'Respondents about the institution', pointing out to the meetings with an expert, also choose forms of documenting the kindergarten, pedagogical consultations, contacts by correspondence, meetings regarding upbringing difficulties, and phone calls. As before, I emphasize that the strength of the correlation is determined by the distance between the points on the scatter plot. The points that represent pedagogical consultations and meetings regarding upbringing difficulties are the closest to each other, which proves the high correlation between these variables. On the other hand, there is a moderate correlation between the meetings with an expert and the forms of documenting the kindergarten with a focus on the pedagogical consultations, and between the forms of documenting the kindergarten and the meetings regarding upbringing difficulties. Observation of successive points on the matrix allows us to conclude that contacts by correspondence and pedagogical consultations are also at a moderate level of correlation, paying attention to the meetings regarding upbringing difficulties and the phone calls. The remaining relations between the determinants are weak.

\section{Discussion}

The research has shown that the determinants strongly influencing the cooperation of Polish kindergarten teachers with institutions / organizations are positive attitudes, the atmosphere of cooperation and social goals. Meetings with experts, additional individual forms, cultural goals and communication are among the weaknesses of this cooperation identified by the 'Respondents about institutions'. The respondents also stated that the cooperation between teachers of Polish kindergartens and institutions / organizations is weakly influenced by the characteristics of cooperation partners ${ }^{5}$.

5 Teacher's age, Teacher's professional advancement level, Teacher's work experience, Teacher's education, Age of cooperation partners, 
The information obtained confirms the belief that it is worth starting shaping attitudes from an early age. The put-in effort pays off in later social relations. In fact, positive attitudes are the factors influencing the construction of the culture of trust that breaks the distance between the pupil and the educator, between the teacher and other adult actors taking part in the staged scenario entitled cooperation. Trust has its depth that allows to take off the straitjacket and throw off the masks to meet other people and start a dialogue. [36] The fundamental assumption of such activities is to organize a tolerant space to achieve total authenticity. Here one can refer to the Cuyahoga County (Ohio) activity report. Namely, the government of Cuyahoga County, to implement the ambitious task of preparing children for success at school and in life, focused on creating friendly conditions for developing partnerships. The attitude of the program authors and implementers contributed to building a partnership network consisting of over 50 institutions. A number of cooperation models were tested to reveal proven and successful strategies. [50] The presented conducted research together with studies in other countries emphasize that the atmosphere of cooperation is often indicated as a determinant of cooperation between kindergarten teachers and institutions / organizations. Undoubtedly, the awareness of the fact that social goals give the direction of cooperation between kindergarten teachers and institutions / organizations reflects the 'Respondents' about institutions' knowledge of care, upbringing, and education, as well as seeing the purposefulness and effectiveness of actions taken. Meanwhile, when undertaking a further analysis of the research results, it is noticeable that teachers of preschool children skip meetings with an expert in educational practice. Failure to perceive the fundamental functions of this form of activity, which crystallize constructs for deepening the knowledge and skills of cooperation partners in the area of upbringing and educating children, may have irreversible effects in creating an atmosphere of cooperation between kindergarten teachers and institutions / organizations. This has further consequences, as the authors of the $\mathrm{CBC}$ report emphasize, in supporting parents in raising their children, as well as in deepening the ties between the family and the kindergarten. [29] From the need to grasp the diversity of attitudes, beliefs, thoughts of participants in the process of cooperation between kindergarten teachers and institutions / organizations and ways of justifying it, so that everything gathered together in a structure could constitute a kind of mental communication, the need to strive for individual meetings "face to face" is noticed. The omission of additional individual forms in the cooperation plans ${ }^{6}$

Education of cooperation partners, Assertiveness of cooperation partners, Communication competences of partners , Partners' experiences in the area of cooperation.

6 Work for the kindergarten; Assisting during classes (parents and adversely affects the exchange of information between partners and building harmonious relationships. For example, open classes are an opportunity for the representative of the institution / organization to assist the teacher. Then, a space for the exchange of experiences and knowledge is created for both partners. On the other hand, polls are an indispensable instrument to collect data on a given topic in order to learn a phenomenon, solve a problem or improve actions.

In this context, actions are taken by The Boston Public Schools Department of Early Childhood to improve the quality of pre-school education so that all children, regardless of race, religion, health, or economic status, prepared to enter grade 1 education are highly recommendable. [24] What is a pure abstraction for others is a source of change for creative and persistent people, an important element of their professional language and active attitude.

As the analysis of this research shows, communication is a rarely mentioned determinant. In such a situation, full contact between partners may be difficult. There is no doubt that the participation of individuals in building a subjective bond, conditioning the further development of cooperation, requires the exchange of thoughts, views and theses. Communication and activities for the common good also fit into the fate of contemporary culture. [37] What is culture? Culture is not only books, paintings, films, exhibitions, architecture, concerts, operas, theatre performances, but also traditions and common poetry, or political events. Culture is not only a guardian and admirer of the past, it is also the creator of a new man and true humanity. In short, culture is a search for beauty in beauty.[3] Meanwhile, today the culture has evolved into a giant supermarket, gallery and consumerism. Advertisements that attract competing consumers have become works of art. People do not want to admire the beauty, to search for the depth of the picture, but to compete on the basis of "who has more". In order for contemporary culture to have enlightened and ennobled recipients, it is necessary to create situations for achieving cultural goals permanently. The analysis of the research results shows that the tasks undertaken in the area of cooperation between kindergarten teachers and institutions / organizations do not very often include cultural goals.

In order to find the consistency of the respondents' answers, the number of indications of individual goals, forms of action, communication, attitudes and other determinants by individual groups of 'Respondents about institutions' was analysed. In the case of goals, the consistency of answers was not demonstrated, which means that each group of respondents indicated different goals. The 'Respondents about institutions' agreed as to

grandparents support the teacher during classes, experts); Polling research; Other individual forms of actions 
the use of the following forms of activity in the cooperation between kindergarten teachers and institutions / organizations: working meetings, meetings on parent pedagogy. Slightly less consistent responses were observed in the case of pedagogical consultations, meetings regarding upbringing difficulties and forms of documenting the kindergarten. The respondents also agreed as to social gatherings and additional individual forms. The strongest consistency of answers occurred in the case of positive attitudes and communication. So, in their opinion, positive attitudes and communication facilitate the cooperation of kindergarten teachers and representatives of institutions / organizations.

And then, by discovering the correlations between the determinants, it has been shown that the most strongly declared working meetings strongly correlate with the meetings on parent pedagogy. Which means that the 'Respondents about the institution' who pointed to working meetings also marked meetings on parent pedagogy. At the same time, it was noticed that both forms are weakly related to the forms of collective communication and do not determine positive attitudes. The curiosity of this phenomenon results from the fact that all above-mentioned determinants, a primarily positive attitudes, together they contribute to the production of changes. This is confirmed by reports from the implementation of the Head Start and State Pre-K programs conducted in the United States. Positive attitudes of representatives of many institutions and state leaders who promoted the partnership of both programs significantly strengthened their relations, and the joint meetings, built trust and understanding. This, in turn, facilitated the early identification of problems, and thus, made it possible to raise education even in the poorest neighbourhoods.[32]

On the other hand, meetings with an expert, as a moderately proposed form of activity of partners of kindergarten teachers and institutions / organizations cooperation, strongly correlate with communication and are poorly related to contacts by correspondence, meetings regarding upbringing difficulties and phone calls. It turned out that meetings with an expert do not determine the atmosphere of cooperation. This means that meetings of this type are not influenced by the atmosphere of cooperation. Meanwhile, the project carried out at the Readnes Centre, which concerned a wide range of topics in the field of cultural diversity, allows us to understand the fact that the favourable atmosphere arranged by its authors contributed to the success of the activities.[27] The results of the described research have shown that strongly exposed positive attitudes of partners are only strongly correlated with communication. In the remaining cases, no dependencies were found.

Although the atmosphere of cooperation is not an appreciated aspect in this case, it actually includes reflectivity based on communication between partners, which is deeply related to the attitudes of partners. Therefore, following Foucault, it should be said that it is difficult to believe in the essential nature of cooperation partners; they are rather entities constructed in a given time and place, subject to discipline and they act as objects and tools at the same time.[12]

The respondents unequivocally stated that pedagogical consultations strongly correlated with meetings regarding upbringing difficulties. In this perspective, they saw the possibility of overcoming upbringing difficulties and shaping the proper model of social relations. In their opinion, individual meetings of parents and teachers in the kindergarten may be supported to a moderate extent by written letters (traditional, electronic) or conversations with an expert. It is also an undeniable fact that, according to the respondents, only direct interactions of interested persons serve to build the child's subjectivity, and the preparation of documentation does not contribute much to the processes of individualization, socialization or emancipation of a child. People associated with Reggio are of a different opinion, as they have developed a reflective pedagogical practice based on documents. [21, 23]

It can be clearly stated that in the cooperation of kindergarten teachers with institutions / organizations, it is important to complement the meetings of partners on various occasions with information on the blog website of the kindergarten or an institution / organization (e.g. invitations, reports and photos from meetings) ${ }^{7}$, as well as public presentation of symbolic and practical works to children (e.g. at fairs, competitions, concerts) ${ }^{8}$. These are specific ways of communication between the participants of a daily dialogue, ensuring the continuity of the message. Communication between the cooperation partners, i.e., of the kindergarten and institutions / organizations, is also included in all kinds of activities aimed at deepening the pedagogical knowledge of parents.

\section{Summary}

Although we do not realize yet, children and all educators are involved in a common discourse on the basis of which upbringing and educational practices develop. The existing constructions are arbitrary, which means that they are neither innocent nor neutral. What emerges from them has a social dimension; the taken solutions not only affect the child, but also the relations between cooperation partners. By participating in practice, gaining experience and observation, partners can build their own vision of participation, recognizing the innocence and individuality of the child, the nonlinearity and uniqueness of time and place. It is essential to

7 Note: That applies to forms of public communication. 8 Note: That applies to social gatherings. 
discover and challenge the beliefs and traditions that are embodied in kindergartens and some institutions / organizations. This will open up a new space and allow to see other possibilities and understand alternative practices. This study comes to meet the above-mentioned ideas. The analysis of the collected data shows the strengths and weaknesses of the cooperation between kindergarten teachers and institutions / organizations in Poland. Among the strengths are:

- Concentration of cooperation partners on social goals and development goals, although a very low level of consistency of the respondents' answers is noticed among them. Meanwhile, social goals explain most forms of activity, except for social gatherings and phone calls. Development goals, on the other hand, are explained by additional individual forms, characteristics of cooperation partners and duration of cooperation;

- Taking into account the duration of cooperation, with a very low level of indication consistency of partners;

- Care for the atmosphere of cooperation, with a low level of consistency in the indications of 'Respondents about institutions';

- Adopting a positive attitude (very high level of indication consistency) by cooperation partners, which correlates with the duration of cooperation as well as very strongly with communication (very high level of indication consistency), and at the same time explains it;

- Organizing meetings regarding upbringing difficulties (high level of indication consistency), which is strongly accompanied by pedagogical consultations (high level of indication consistency) and moderately accompanied by contacts by correspondence (average level of indication consistency);

- Quite frequent phone calls (low level of consistency of indications) and accompanying them contacts by correspondence (average level of consistency);

- Strong correlation of meetings on parent pedagogy with working meetings; in this case both forms are indicated simultaneously by all respondents (high level of consistency);

- Noticing the benefits for each of the parties to the cooperation, which are explained by the forms of action and characteristics of cooperation partners, the atmosphere of cooperation, duration of cooperation and communication.

Under these conditions, it could be stated at first glance that the level of consistency of indications is not always related to the frequency of indications. The disclosure of the relations taking place is not only among the forms of activity, but also among other aspects of cooperation, allowed for capturing the most specific and hidden values of cooperation. Everything indicates that the cooperation of kindergarten teachers with institutions / organizations is a multifactorial process. The weaknesses of the relations between the partners of the cooperation between kindergarten teachers and institutions / organizations include:

- Low frequency of indicating cultural goals, as well as a very low level of consistency in the respondents' statements;

- Rarely proposed by the partners meetings with an expert and forms of documenting the kindergarten, with the corresponding medium and high levels of consistency;

- Failure to perceive the role of pedagogical consultations, meetings on parent pedagogy, social gatherings, working meetings and additional individual forms, with a very high and high levels of consistency of indications;

- Poor relations between the forms of public communication and meetings on parent pedagogy, additional individual forms and working meetings; whereas in other cases no connections are noticed (apart from working meetings);

Weak correlation of the forms of documenting the kindergarten with contacts by correspondence, meetings regarding upbringing difficulties and pedagogical consultations;

- Insufficient relations between meetings with an expert and contacts by correspondence, meetings regarding upbringing difficulties and phone calls;

- Locking on synchronization of the atmosphere of cooperation and forms of activity;

\section{Recommendations}

The new cooperation model should be based on:

- Assigning new roles to parents, local authorities, national and international institutions / organizations, politicians, researchers in the process of cooperation between kindergarten teachers and institutions / organizations, defining each of them as those worthy of sharing their knowledge and experiences. They have a chance to co-create cooperation programs at various times in the specific space allocated to them by kindergartens and institutions / organizations;

- The recognition of cultural goals as those that guide the activities of cooperation partners towards equalizing the cultural capital of children from different social backgrounds. Taking into consideration the fact that the inequality of cultural capital is attributed to learning outcomes;

- The creation of a pleasant atmosphere around the participants of the planned cooperation process. Departure from the routine of activities manifested, inter alia, by the permanent duplication of the same forms of activity; 
- The neutralization of the neutral and negative attitudes revealed by partners from different social groups, or a fortiori, by children whose parents belong to different social groups. This statement is meaningless and will remain the source of absurdity until the partners are motivated to work on each other;

- The expenditure of the partners' linguistic capital, which will improve the process of communication and establishing relationships with the world. [26] In this approach, the context of communication is understood as the language and means of expression. It can be said that the world is not constant; it is changeable in our eyes and is subject to various interpretative activities. Language is a tool for building a network of cooperation between kindergartens and institutions / organizations, the forms of which are intertwined. The forms of action are produced by thoughts, language, and communication processes, therefore they are not viewed as immutable. On the contrary, they are deconstructed and reconstructed, and possibly, the dominant and oppositional forms of action are removed to the background. All measures should be undertaken keeping in mind the possibilities of emancipatory practice in kindergartens and the implementation of democratic solutions;

- The adopted directions and visions of partners' activities, which should be elements included in the process of documentation. Constructing, for example, a plan of cooperation between a kindergarten teacher and institutions / organizations, or cover letters to sponsors and the invitations themselves, is an unprecedented challenge. Documents provide the insight into the participation carried out, a critical review of the actions taken, and their thorough improvement. It allows to move from concept to practice and back to develop mutual listening, to become aware of one's own abilities and control over actions. The choices recorded in it are one of the many embedded in the context. Documentation has another meaning as well, namely, it allows people to take responsibility;[10]

- The participation of parents, representatives of institutions / organizations, kindergarten teachers, and often the recognition of children's desires, when building a cooperation program, i.e. choosing goals, forms of action, defining tasks to be performed, and methods of work and tools to be used;

- The recognition of such forms of activity as meetings with an expert, working meetings, or meetings on parent pedagogy, which serve to increase the level of empathy and trust of partners, and to activate their self-reflection and self-esteem. At the same time, they counteract educational failures and minimize the risk of excluding some individuals from society;
Making partners aware of the benefits of joint intellectual and concrete activities, given that kindergartens attract children and their parents from different social groups in an unequal way.

An a posteriori model of cooperation, based on exposed pillars, has a chance to lead to the determination and shaping of the partnership relations in the society. This would mean a re-translation of losses into benefits in the economic field. To put it more precisely, it would mean shaping individuals with a sophisticated taste for finding themselves in social reality. In the context of specific research goals, the cooperation model thus defined allows to outline fully the following paradigms: cooperation requires the partners to reflect on themselves; cooperation is based on working at oneself; cooperation creates empathy and trust; cooperation expands linguistic and cultural capital; cooperation offers a new quality life in partnership relations; it is a product of transformations taking place over time.

Ultimately, it can be said that kindergartens in a postmodern democratic world cannot exist as isolated institutions. Only collective action can develop cooperation among its members; as the American political scientist Robert Putnam claims, "the denser such networks are in society, the more likely it is that citizens will be able to cooperate for mutual benefit". [28]

\section{REFERENCES}

[1] Babbie E., "Podstawy badań społecznych," Wydawnictwo Naukowe PWN, Warszawa 2008.

[2] Bałachowicz J., Witkowska-Tomaszewska A., "Edukacja wczesnoszkolna w dyskursie podmiotowości. Studium teoretyczno-empiryczne," Wydawnictwo Akademii Pedagogiki Specjalnej, Warszawa 2015.

[3] Bauman Z., "Globalizacja," Państwowy Instytut Wydawniczy, Warszawa 2020.

[4] Bauman Z., "Kultura w płynnej nowoczesności," Narodowy Instytut Audiowizualny, AGORA SA, Warszawa 2011.

[5] Bujak A., Topolska K., Topolski M., "The Use of Cluster Analysys and the Theory of Mathematical records the Process of Planning the Production-Warehouse Flow, " Reserch in Logistics \& Production, vol. 6, no. 3, pp. 259267, University of Technolog, Poznań 2016, https://www.wbc.poznan.pl/dlibra/publication/532075/editi on/439780? language=pl\#description (accessed November 11.2020). DOI: $10.21008 /$ j.2083-4950.2016.6.3.6

[6] Burr V., "Social Constructionism," UK Taylor \& Francis, London 2003.

[7] Chałasiński J., Społeczeństwo i wychowanie. Socjologiczne zagadnienia szkolnictwa i wychowania, Nasza Księgarnia, Warszawa 1974. 
[8] Clegg F., "Po prostu statystyka," Wydawnictwa Szkolne i Pedagogiczne, Warszawa 1994.

[9] Cypryańska M., Bedyńska S., "Porównywanie dwóch grup: testy t-Studenta i ich nieparametryczne odpowiedniki," in Statystyczny drogowskaz. Praktyczny poradnik analizy danych $w$ naukach społecznych na przykładach $\mathrm{Z}$ psychologii, S. Bedyńska, A. Brzezińska (eds.), Wydawnictwo Szkoły Wyższej Psychologii Społecznej " Academica", Warszawa 2007, pp. 203-204.

[10] Dahlberg G., Moss P., Pence A., "Poza dyskursem jakości w instytucjach wczesnej edukacji i opieki," Wydawnictwo Naukowe Dolnośląskiej Szkoły Wyższej, Wrocław 2013, pp. 81, 221-223.

[11] Flower R., "Language in the News. Discourse and Ideology in the Press," Routladge, London-New York 1996, p. 25.

[12] Foucault M., "Nadzorować i karać. Narodziny więzienia," T. Komendant (trans.), Fundacja Aletheia, Warszawa 2009, p. 167.

[13] Greenacre M. J., "Theory and applications of correspondence analysis," Academic Press, New York 1984.

[14] Greenacre M. J., "Correspondence analysis of multivariate categorical data by weighted least-squares," in Biometrika, vol. 75(3), pp. 457-467, 1988. DOI: 10.1093/biomet/75.3.457

[15] Hessen S., "Podstawy pedagogiki, " A. Zieleńczyk (trans.), Wydawnictwo „Żak”, Warszawa 1997.

[16] Howie E. K., Brewer A., Brown W. H., Pfeiffer K. A., Saunders R .P and Pate R. R., "The 3-year evolution of a preschool physical activity intervention through a collaborative partnership between research interventionists and preschool teachers," Health education research, vol. 29(3), pp. 491-502, $2014 . \quad$ DOI: https://doi.org/10.1093/her/cyu014

[17] Jagiełło E., "Cooperation as element of well-balanced child's development," $9^{\text {th }}$ International Conference on Education and New Learning Technologies Barcelona, Spain 3-5 July, 2017, Publisher: IATED. DOI: https://doi.org/10.21125/edulearn.2017, pp. 8868-8879.

[18] Key E., "Stulecie dziecka," I. Moszczeńska (trans.), Wydawnictwo Akademickie „Żak”, Warszawa 2005.

[19] Koronacki J., Mileńczuk J., "Statystyka dla studentów kierunków technicznych i przyrodniczych," WNT, Warszawa 2001, pp. 476-478.

[20] Kruskal W. H., Wallis W. A., "Use of Ranks in One-Criterion Variance Analysis," Journal of the American Statistical Association, vol. 47, no. 260, pp. 583-621, Dec. 1952. URL: http://www.jstor.org/stable/2280779

[21] Lindsay G., "Reflection in the Mirror of Reggio Emilia's Soul: John Dewey's Foundational Influence on Pedagogy in the Italian Educational Project," Early Childhood Educational Journal, vol. 43(6), pp. 447-456, 2015. DOI:10.1007/s10643-015-0692-7

[22] Łobocki M., "Metody i techniki badań pedagogicznych," Oficyna Wydawnicza "Impuls", Kraków 2006.

[23] MacDonald M., "Review of Kathy Hall et al. Loris
Malaguzzi and the Reggio Emilia Experience," Studies in Philosophy and Education, vol. 30(6), pp. 631-639, 2011. DOI: $10.1007 / \mathrm{s} 11217-011-9224-0$

[24] Marshall N.L., Roberts J., Mills L., "Boston Public Schools K1 and K2 Programs Needs Assessment," Internal Report to the Department of Early Childhood, Boston Public School, 2006, https://www.researchgate.net/publication/234593211_Bost on_Public_Schools_K1_and_K2_Programs_Needs_Assess ment_Internal_Report_to_the_Department_of_Early_Child hood_Boston_Public_Schools (accessed Nov. 10, 2020)

[25] Okoń W., Nowy słownik pedagogiczny, Wydawnictwo Akademickie „Żak”, Warszawa 1998.

[26] Patton Ch., Wang J., "Ready for Success: Creating Collaborative and Thoughtful Transitions into Kindrgarten," 2012 - This paper was prepared by the Harvard Family Research Project with support from SEDL for the National PIRC Coordination Center, a project of SEDL in collaboration with the Harvard Family Research Project. It was produced in whole or in part with funds from the U.S. Department of Education under contract No. ED-04-CO-0039/0001,

https://www.oregon.gov/ode/educator-resources/Document s/readyforsuccess.pdf (access 05.12.2020).

[27] Pelletier J., Corter C., "Design, Implementation, and Outcomes of a School Readiness Program for Diverse Families," The School Community Journal, vol.15, no. 1, Spring/Summer 2005, pp. 89-116, http://www.adi.org/journal/ss05/Pelletier\%20\&\%20Corter. pdf (access 09.12.2020).

[28] Putman R., Demokracja w działaniu. Tradycje obywatelskie we współczesnych Włoszech, J. Szacki (trans.), Wydawnictwo "Znak", 1995, p. 269.

[29] Sheridan S.M., Holmes S.R., Coutts M.J., Smith T.E., Kunz G.M., Witte A.L, "CBC in Rural Schools: Preliminary Resolts of a Randomized Trial," 2013, Development of this working was completed at the Nebraska Center for Research on Children, Youth, Families and Schools (CYFS), funded by a grant from the U.S. Department of Education's Institute of Educational Sciences (R324A100115),

https://files.eric.ed.gov/fulltext/ED565481.pdf (access 02.12.2020).

[30] Sośnicki K., "Rozwój pedagogiki zachodniej na przełomie XIX i XX wieku," PZWS, Warszawa, p. 92, 1967.

[31] Sośnicki K., "Teoria środków wychowania," Nasza Księgarnia, Warszawa, 1973, pp. 8-9.

[32] Stebbins H., Scott L.C., "Better Outcomes for All: Promoting Partnerships between Head Start and State Pre-K," Arlington, Virginia, Washington 2007; http://research.policyarchive.org/13722.pdf (access 09.12.2020).

[33] Szwed R., "Metody statystyczne w naukach społecznych. Elementy teorii i zadania," Wydawnictwo KUL, Lublin 2008, pp. 239-247, 267-272.

[34] Szymański M. J., "Rodzice i szkoła w procesie gwałtownej zmiany społecznej," in Nauczyciele i rodzice. W poszukiwaniu nowych znaczeń i interpretacji współpracy, I. Nowosad, M. J. Szymański (eds.), Oficyna Wydawnicza 
UZ, Kraków AP, Zielona Góra - Kraków, 2004.

[35] Śliwerski B., "Klinika szkolnej demokracji," Oficyna Wydawnicza "Impuls", Kraków 2008, s. 36.

[36] Śliwerski B., "Współczesna myśl pedagogiczna. Znaczenia, klasyfikacje, badania," Oficyna Wydawnicza "Impuls", Kraków 2011, p. 204.

[37] Śpiewak P., "Obietnice demokracji. Pejzaże myśli," Prószyński i S-ka, Warszawa, p. 76, 2004.

[38] Thompson L., Halfon N., Franke T., "An Action Plan: Assessing School Readiness in Ventura County," UCLA, Center for Healthier Children, Families and Communities, 2004, https://files.eric.ed.gov/fulltext/ED496872.pdf (access 05.12.2020).

[39] Topolski M., "The Modified Principal Component Analysis Feature Extraction Method for the Task of Diagnosing Chronic Lymphocytic Leukemia Type B-CLL," Journal of Universal Computer Science 26(6), 2020, pp. 734 - 746,

[40] http://www.jucs.org/jucs_26_6/the_modified_principal_co mponent/jucs_26_06_0734_0746_topolski.pdf (access 01.12.2020).

[41] Topolski M., "Algorithm of Multidimensional Analysis of Main Features of PCA with Blurry Observation of Facility Features Detection of Carcinoma Cells Multiple Myeloma," in Progress in Computer Recognition Systems, CORES 2019. Advances in Intelligent Systems and Computing, vol. 977, 2020, pp. 286-294, Springer, Cham. DOI: 10.1007/978-3-030-19738-4_29

[42] Topolski M., Topolska K., "Algorithm for Constructing a Classifier Team Using a Modified PCA (Principal Component Analysis) in the Task of Diagnosis of Acute Lymphocytic Leukaemia Type B-CLL," Hybrid Artificial Intelligent Systems, Garcîa H. P., González L. S., Limas M. C., Pardo H. Q. and Rodriguez E. C. (eds.), Hybrid Artificial Intelligent Systems $-14^{\text {th }}$ International Conference, HAIS 2019, León, Spain, September 4-6, 2019, Proceedings, Springer International Publishing, 2019, pp. 614-624.

[43] Topolski M., "Application of the Stochastic Gradient
Method in the Construction of the Main Components of PCA in the Task Diagnosis of Multiple Sclerosis in Children," International Conference on Computational Science 2020, Lecture Notes in Computer Science, volume 12614, Krzhizhanovskaya V. V., Závodszky G., Lees M. H., Dongarra J. J., Sloot M. A., Brissos S. and Teixeira J. (eds.), Springer, 2020, pp. 35 - $44 . \quad$ DOI: 10.1007/978-3-030-50423-6 3

[44] Winiarski M., "Rodzina - szkoła - środowisko lokalne. Problemy edukacji środowiskowej, Instytut Badań Edukacyjnych, Warszawa 2000.

[45] Winiarski M., "Współdziałanie szkoły i środowiska: aspekt socjologiczny, " Uniwersytet Warszawski, Warszawa 1992.

[46] Znaniecki F., "Socjologia wychowania, " t.1, Państwowe Wydawnictwo Naukowe, Warszawa 1928.

[47] Znaniecki F., "Socjologia wychowania," t.2, Państwowe Wydawnictwo Naukowe, Warszawa 1930.

[48] Ministerstwo Edukacji Narodowej o wychowaniu w szkole, Biblioteczka Reformy nr 13, Warszawa 1999.

[49] "Edukacja. Jest w niej ukryty skarb," Raport UNESCO Międzynarodowej Komisji do spraw Edukacji dla XXI wieku, under the leadership Deloresa J., Warszawa 1996.

[50] "Internetowy podręcznik statystyki,"

[51] https://www.statsoft.pl/textbook/stathome_stat.html?https $\% 3 \mathrm{~A} \% 2 \mathrm{~F} \% 2 \mathrm{Fwww}$.statsoft.pl $\% 2$ Ftextbook $\% 2$ Fstcoran.ht $\mathrm{ml}$ (access 10.10.2018)

[52] "Cuyahoga County Early Childhood Initiative Evaluation: Phase II Final Report. Executuve Summary," Center Urban Poverty and Social Change, 2005. https://files.eric.ed.gov/fulltext/ED533518.pdf (access 15.12.2020).

[53] https://www.npseo.pl/action/raports (access 22.04.2021)

[54] https://ec.europa.eu/programmes/erasmus-plus/projects/\#se $\mathrm{arch} /$ project $/$ keyword $=$ cooperation $\% 2520$ kindergarten $\& \mathrm{ma}$ tchAllCountries $=$ false $($ access 22.02.2021) 